\title{
The Development of Instructional Materials E-Learning Based On Blended Learning
}

\author{
Andi Kristanto $^{1}$, Mustaji $^{1}$ \& Andi Mariono ${ }^{1}$ \\ ${ }^{1}$ Universitas Negeri Surabaya, Indonesia \\ Correspondence: Andi Kristanto, Universitas Negeri Surabaya, Indonesia. E-mail: andikristanto@unesa.ac.id
}

Received: January 28, 2017

Accepted: February 28, $2017 \quad$ Online Published: June 27, 2017

doi:10.5539/ies.v10n7p10

URL: https://doi.org/10.5539/ies.v10n7p10

\begin{abstract}
The use of e-learning is becoming the global issue now. In an educational field, there are many institutions already use it. The study very important aimed to test the feasibility and effectiveness the development of instructional materials e-learning based on the blended learning in audio/radio media development course. The background laid behind the problem is the experience the students had that is having difficulties in developing the audio/radio media manuscript. This caused by the limited time lecturer had to explain the screenwriting material, and duration the students had to write the audio/radio script, so it affected the lack of students' understanding of the course material also to the students' scriptwriting result which is not feasible to produce yet. Standard mastery of the subject specified within 6 (six) weeks in maximum, and the students should have been able to develop the script established on the rules of production. Thus, the outcome of this research would be the e-learning-based instructional materials based on blended learning, Semester Lesson Plan (SLP) audio/radio media. This inquiry aims at the improvement of the quality of the work of the audio/radio manuscript. This study implements the Research and Development methodology which is based on the steps generally refers to the opinion of Borg and Gall. The R \& D steps was done with modified to simplify it into three main stages, namely the introduction, the development, and testing. Data obtained from the learning experts get the percentage of $91.67 \%$, the course professionals and media specialists each earn a percentage of $100 \%$. Based on these data, the model of blended learning instructional materials for the development of audio/radio media course that have been developed could be the solution of the research question stated that blended learning models of instructional materials that have been evolved are practical for use in learning instructional activity.
\end{abstract}

Keywords: development, instructional material, e-learning, blended learning, R \& D

\section{Introduction}

Every effort and a conscious determination in the learning process is nothing but to improve the quality of learning. Various models have been established starting from the beginning of learning process with the direct face-to-face meet up with the students up to the state where there is no meet up needed, but still would be facilitated by kind of online classes. The development of the Technology of Information and Communication is so swiftly changed affecting the learning activities of outside-guided to be self-guided centered. It also completed because the ease of internet access which makes e-learning is increasingly being popular in education. According to Miarso (2004), the use of e-learning will never separate from the use of internet access. The information obtained from the sites is rather complete so that it affects lecturer's task in the instructional learning process. It used to be this situation where the lecturer's control almost all the input, then the learning environment did develop where the books and lecturer both dominating the input, and will come the time where both books, lecturer, and technology would all dominating the input on the learning process.

In globalization era, through the enhancement of technology surely growth hastily, allowing the students even able to learn more effectively and efficiently. One of the ways is to making use of the internet access as one of the alternatives to get the learning sources. The use of e-learning based on blending learning for this one is not only applicable for long-distance class but also could be developed into a good use for the conventional education system. The development of audio/radio media is one of course subjects which is must be taken by the students of the undergraduate program of Technology of Education in the Faculty of Education of State University of Surabaya, Indonesia. One proficiency must be master by the students in this course includes developing audio program script. 
A good script will determine the program's quality also it could be a guild for both directors and another production team while the recording happened. Audio media script contains the sounds queue, both human's lines, music, and other sound effects which could support the creation of any mood on the program that recorded. Script development competency is having a high difficulty that it needs strong determination and higher creativity in the creation. The understanding about the use of audio language, parties on music and sound effects, also the scriptwriting technique must be mastered by the students before jump into the process of the creation of learning the audio script.

Based on the observation and interview results also to look in the state of the course, especially when it comes to the part of creating the script, there are some problems which seem need to be solved immediately, and those problems happened in each year when the students have to take the course. In the practical case, most of the students happened to struggle in developing the audio/radio media script. The case happened due to the time limitation the lecturer had in explaining the lesson related to scriptwriting and the time limitation the students had to do their task so that it cause less understanding by the students on this course. Also there are many of the practice results are not feasible to established. The standard time set to master the course limited in six weeks in maximum, and the students should have been able to develop the script in a result where it would be fit to the standard production.

The number of constraints that occurred during the implementation of the learning process, such as lecture hours which are sorely lacking come along with kind of materials or instructional content that is too much is one of the factors the underlying idea to develop an e-learning-based blended learning. Within this model of blended learning instructional materials, we expect to be able to overcome all the obstacles that exist; also it has Semester Lesson Plan (SLP) at each meeting for related course. So the learning will be done following the pattern of the learning media that have been created. Only for some periods, meet up the class dismissed and the class would run online so that the class would be still available by using online learning system without decreasing any understanding in the course materials. Based on the need to develop the quality of instructional learning process on this course, it would be better to set the focus on the lack of time duration the class had. To exclude the students directly on the materials delivery should be taught that is by developing e-learning activity based on blended learning which supports the conventional learning system could be a solution.

Based on the facts have been stated above, the researcher feels the urge to develop e-learning based on blended learning that could be studied independently by the students outside the class hours which is well-matched both with the materials and students' characteristic. The problem would likely happen in the process of the media development is the nippy way to groups on, executes, and renewing a learning and practice program (Sadiman, 2016:2). Referring to Anderson's statement, it seems that to be a researcher means must be really understanding on the characters of media, materials, and the students. Just so the media could be used to enhance the students' learning quality.

Based on the need analysis done, it could be concluded that there will be e-learning development based on blended learning required to do for audio/radio media development course. The reason is that the characteristic of the utensil of blended learning based e-learning is deemed to be the most suitable relating on the problems happened. In the other hand, it also could be learned independently, students-oriented. Based on the description stated above, the conclusion for the research question would be "Is blended-learning instructional models for audio/radio media development course is practicable for the students of Curriculum and Technology of Education, Faculty of Education, State University of Surabaya, Indonesia?"

\section{Context and Review of Literature}

Blended-learning is defined by etymologic from the word blended and learning, blended means a mixture combination alignment (Oxford English Dictionary) in (Heinze \& Procter, 2004:236). While learning explained as the act to understand or to comprehend something, etymologically it could be concluded as the combination of the practical from instructional learning activity. Blended-learning is a flexible approach where its program includes a combination of various places and times that could be used to study. Based on Semler (2005): "Blended Learning combines the best aspects of online learning, structured face-to-face activities, and real-world practice. The aspects such as Online learning systems, classroom training, and on-the-job experience hold the biggest part as an obstacle. The Blended Learning approach uses the strengths of each to retaliate the others' deficiency."

According to Rovai and Jordan (2004, p. 3) the instructional models of blended learning is a combination of excellence in learning done by face to face (face-to-face learning) and the virtual (e-learning) ones. The instructional material of blended-learning is a model that combines learning system face-to-face and virtual 
learning system. This combination, according to Whitelock and Jelfs (2003), gives three terms to Blended Learning, namely: a. The integrated mix of traditional learning with web-based online approaches (drawing on the work of Harrison); b. The blending of media and tools employed in an e-Learning environment; $c$. The combination of some pedagogic approaches, irrespective of learning technology use (drawing on the work of Driscoll). There are three of them according to Whitelock and Jelfs (2003), namely: a) fusion/integration of traditional learning approaches to web-based on-line (drawing on the work of Harrison); b) a combination of media and equipment used in e-learning environment and; c ) a combination of a number of pedagogical approaches regardless of the technology used (drawing on the work of Driscoll).

According to Sharpe, et.al (2006) Blended e-learning characteristics includes: Statutes resources to supplement learning programs related to most of the traditional line, through institutional support virtual learning environment; Transformative level instructional practices supported by up-depth learning design; A holistic view of technology to support learning. From the characteristics above, the distinctive of blended learning are the source of the supplement, with the traditional approach which also supports virtual learning environment through an institution, learning design focusing at the time of grade changes instructional practices and views about all of the technology used to support learning (Riyana, 2010). The characteristics of blended learning based on the previous statement is; first about the instructional materials, blended learning is an additional source for the conventional learning supported by the virtual happened, changes in the practice of the implementation of learning that includes specially designed, and the use of technology that is thorough in its implementation.

Approach to the learning theory underlying the application of the instructional materials of blended-learning models aimed at keeping the goals settled could be achieved outstandingly. Based on the understanding of the instructional materials of blended-learning models, means it is combinations of learning models so that learning theory used also vary according to the circumstances of learners and the course environment. To identify about the learning theory used, it is needed to know in the components included in the instructional materials in blended-learning. The fundamental of the instructional materials of blended-learning are face-to-face learning, web-based learning, online learning, computer-based learning, internet based learning, and e-learning.

The model for the instructional materials is composed of by the experts based on the principal of instructional learning activity, psychological theory, sociology, system analysis, or other theories supporting (Joyce \& Weil, 2000). According to Rusman (2015, p. 133), the course model is a plan or pattern which can be used to from a curriculum (a long-session lesson plan), crafting for instructional materials, also to guide the instructional process in the class, etc. Based on Joyce and Weil (2000, p. 13), it is stated that course model is a description of the learning environment which portraying the curriculum plan, classes, instructional designs, class materials, textbooks, workbooks, and instructional aids through a computer. This model is an instructional design which in its practical provides a media for the students. Sagala (2012, p. 176) argued that this learning model be a conceptual framework that describes a systematic procedure in organizing the learning experience of students to achieve specific learning objectives, and serves as a guide for learning designer and lecturer in planning and implementing learning activities.

\section{Methods}

This study was applying the design of research and development (Research and Development). It is related to the main purpose of this research which is to determine on what kind of Blended Learning model that could be developed at Department of Curriculum and Educational Technology, State University of Surabaya, Indonesia, also the potential support that can be strived to develop a blended learning model of learning in Department of Curriculum and Educational Technology, State University of Surabaya, Indonesia. As described by Borg and Gall (1989, p. 772), "Educational research and development (R \& D) is a process used to develop and validate educational products. The steps of this process are usually referred to the R \& D cycle that subsists of studying research findings application to the product to be evolve, advancing the product based on the discovery, field testing the product in the framework where it will be used ultimately, and revising it to correct the weaknesses found in the field of testing stage. In indicating that the product meets its behaviorally defined objectives".

Which means research and educational development $(\mathrm{R} \& \mathrm{D})$ is a process used to develop and validate a product in education. The steps in this process are generally known as the cycle of R \& D which consists of an assessment of the results of previous studies related to the validity of the components in the product to be developed, to develop it into a product, to test the brand designed and to review also correcting it based on trial. It was an indication that the findings of product development activities undertaken have objectivity. Product education (educational product) within the term has a broad meaning and includes not only material beings such as textbooks, instructional videos and such but also to the development of processes and procedures, such as the 
advancement of a method or model. With that in mind, the approach to research and development is seen to have the procedural steps making it easier for developers to be able to go through each step, and this model has a methodical sequence so as to produce a viable media for use in the learning process. The measures contained in this model basically has two (2) goal is to develop products and test the effectiveness of the product to achieve goals.

\section{Findings}

The development of blended learning instructional material based on the steps in the development model of Research \& Development (R \& D). Following is the description in the development of instructional materials of blended-learning model:

\subsection{Research and Information Collecting}

The first step conducted by researchers in developing models of blended learning instructional materials on the development of audio/radio media course for students majoring in Curriculum and Educational Technology Faculty of Education, State University of Surabaya, Indonesia, is to conduct research and gather information. Based on the observations conducted, there are some real conditions (real) in learning identified as follows: The situation of the course in audio media development especially for script development material happened to have some problems which seemed net to be solved immediately. There, the problem happened on each year when the students taking the course. In practical, most of the students found it difficult to develop audio/radio media script; then it affected on the less understanding towards the lesson also to the outcomes which was not well-standardized to establish. The standard time limitation to master the course is six weeks in maximum, and the students should have been able to develop a script using the standard production; The audio/radio media development is one of the courses that must be taken by the students in undergraduate program of Technology of Education, Faculty of Education, State University of Surabaya, Indonesia. One of the competency must be master by the students in this course is to develop the audio script.

\subsection{Planning}

The next thing to do after founding the false on the course is to gather information as the contents to make a plan for the product used to resolve the problems. Based on the situation observed, the researcher developed instructional materials of blended-learning well-matched for the audio/radio media development course, these models are the combination between both face-to-face learning and online learning. In planning the product, things should be done by the researcher is to make the Semester Lesson Plan (SLP) draft and flowchart web. To get the process done well, the researcher did obtain data gathering about facility the students had which can be used to executes the model that have been prepared. Based on the data gathered by class observation, the result is 47 students own laptop, in total 39 units; 35 units of portable wifi spot; 34 units gadget; and six (6) units personal computers.

\subsection{Develop Preliminary Form of Product}

The development stages of preliminary form of the product stated below: Semester Lesson Plan (SLP) modification, in this phase, the researcher modified the Semester Lesson Plan (SLP) which is created in conventional model to the another model using two styles of learning that is face to face learning style and the only ones. The previous Semester Lesson Plan (SLP) is made by the lecturer of audio/radio media development course. The goal of this modification is to match the learning environment with the instructional activity and to achieve the course goals maximally; Materials framework, in this stage the researcher composed the materials that would be used in the instructional activity together with the lesson expert. The objective of this phase is to get to know kind of materials should be mastered by the students so that they could achieve the objectives of the course. The materials delivered in the class should lure the students, especially who takes on this course so that the students would comprehend the lesson in complete and ease. In this material development, it could be done by having a session with the lecturer team who obliged to deliver the course. Pre-production, before doing the e-learning media production that would be used as instructional materials for blended learning, a web design is needed. The trial on e-learning design was done as the standard for success rate in developing the prototype so that the media would turn out applicable in an instructional learning activity. The trial is done by having a session with the experts both on materials and media related to the materials that will be delivered and developed. 


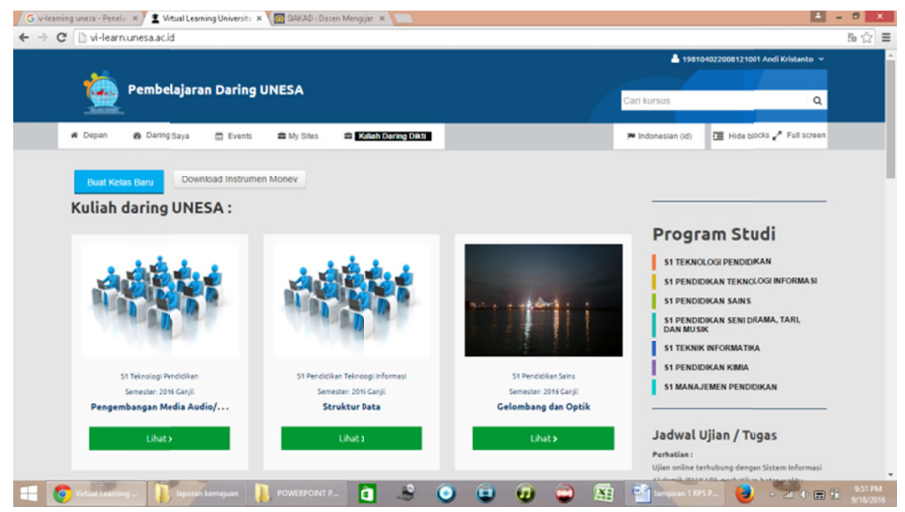

Picture 1. E-Learning Design

Production, on this blended-learning model development, on its making of the e-learning system, a program named PopojiCMS which is a Content Management System used to create the concept in e-learning, the program is also the main program utilized. In the production process, there is some supporting program such as Adobe Photoshop CS3, CorelDraw X4 and Microsoft Word 2010. Adobe Photoshop CS3 was used to edit pictures; it would be edited into such format to use in the media. CorelDraw X4 was used to create pictures and set the size of the pictures used in the media. Microsoft Word 2010 is used to process the data needed on the web which would be featured in the blended learning instructional; Materials Included: These materials are the guidance material for the lecturers which includes the Semester Lesson Plan (SLP), the guide on the use of e-learning, guides on materials and practice; It is available on soft file.

\subsection{Preliminary Field Testing}

Preliminary Field Testing is an activity process to review the prototype of the product developed. The goal of this stage is to know about the lack the product has. This validation aimed to two of instructional design experts, two materials experts, and two more of media experts, by having a structured interview, Below is the explanation on the detail of this validation, both from each point of view; the instructional design experts, material design experts, and media design experts:

\subsection{Instructional Design Experts' Validation}

Experts' validation began by doing a trial on the blended-learning model. In this development, the one who cast as the experts were two lecturers of Curriculum and Technology of Education Program of State University of Surabaya, Indonesia. Criteria: Very Good $(V G)=4$, $\operatorname{Good}(G)=3, \operatorname{Bad}(B)=2$, Poor $(P)=1$

Table 1. Result of instructional design experts' I and II

\begin{tabular}{|c|c|c|c|c|c|c|c|}
\hline \multirow{2}{*}{ Variable } & \multirow{2}{*}{ Sub-variable } & \multirow{2}{*}{ Indicator } & \multicolumn{4}{|c|}{ Scores range } & \multirow{2}{*}{ Scores } \\
\hline & & & 1 & 2 & 3 & 4 & \\
\hline \multirow{15}{*}{ Practicability of model } & \multirow{4}{*}{ Goals Framework } & Audience & 0 & 0 & 0 & 2 & 8 \\
\hline & & Behavior & 0 & 0 & 1 & 1 & 7 \\
\hline & & Condition & 1 & 0 & 0 & 1 & 5 \\
\hline & & Degree & 0 & 1 & 0 & 1 & 6 \\
\hline & \multirow{4}{*}{ Method } & Materials Delivery & 0 & 0 & 1 & 1 & 7 \\
\hline & & Students' Orientation & 0 & 0 & 1 & 1 & 7 \\
\hline & & Exercises & 0 & 0 & 0 & 2 & 8 \\
\hline & & Material access & 0 & 0 & 0 & 2 & 8 \\
\hline & \multirow{3}{*}{ Strategy } & Materials and media preparation & 0 & 0 & 1 & 1 & 7 \\
\hline & & Learning environment & 0 & 0 & 0 & 2 & 8 \\
\hline & & Students' preparation & 0 & 0 & 0 & 2 & 8 \\
\hline & \multirow{3}{*}{ Participation rate } & Students' participation rate & 0 & 0 & 0 & 2 & 8 \\
\hline & & Students' independency & 0 & 0 & 0 & 2 & 8 \\
\hline & & Assignments & 0 & 0 & 0 & 2 & 8 \\
\hline & Evaluation & Learning Evaluation & 0 & 0 & 1 & 1 & 7 \\
\hline
\end{tabular}


Based on Table 1 about the result of instructional design validation by having two respondents that were the experts, things defined as:

$$
\mathrm{PSA}=\frac{26+30+23+24+7}{4 \times 15 \times 2} \times 100 \%=91.67 \%
$$

From the description stated above, as the conclusion, it is most likely that all the aspects reviewed by the experts got the score as much as $91.67 \%$. That percentage is acknowledged as the good ones, that so the learning model is practicable to be used in the audio/radio media development course in Curriculum and Technology of Education Program, Faculty of Education, State University of Surabaya, Indonesia.

\subsection{Material Experts' Validation}

Experts' validated by observing on how the trial was done on the blended-learning model in audio/radio media development course. In this advancement, the one who cast as the experts were two lectures of Curriculum and Educational Technology Program, Faculty of Education, State University of Surabaya, Indonesia. Criteria: Yes = $1, \mathrm{No}=0$

Table 2. Result of the review of material expert I and II

\begin{tabular}{|c|c|c|c|c|c|}
\hline \multirow{2}{*}{ Variable } & \multirow{2}{*}{ Sub-Variable } & \multirow{2}{*}{ Indicator } & \multicolumn{2}{|c|}{ Score } & \multirow{2}{*}{ Percentage } \\
\hline & & & 1 & 0 & \\
\hline \multirow{8}{*}{$\begin{array}{l}\text { Materials } \\
\text { Feasibility }\end{array}$} & \multirow{8}{*}{$\begin{array}{l}\text { Instructional } \\
\text { materials }\end{array}$} & Underlying Ideology & 2 & 0 & $100 \%$ \\
\hline & & Material delivered based on the learning goals & 2 & 0 & $100 \%$ \\
\hline & & Pre-test as students' preparation & 2 & 0 & $100 \%$ \\
\hline & & Accuracy in Materials delivery & 2 & 0 & $100 \%$ \\
\hline & & $\begin{array}{l}\text { Materials uploaded to the web as the independent } \\
\text { learning source }\end{array}$ & 2 & 0 & $100 \%$ \\
\hline & & Learning activity to achieve learning goals & 2 & 0 & $100 \%$ \\
\hline & & Excercises & 2 & 0 & $100 \%$ \\
\hline & & Evaluation reviewing the success rate & 2 & 0 & $100 \%$ \\
\hline Average & & & & & $100 \%$ \\
\hline
\end{tabular}

As could be seen in the table above, the data analysis concluded has $100 \%$ average and could be referred as a well-done delivery.

\subsection{Media Experts' Validation}

Experts' validation is done by two experts. In this blended-learning model by using web media, reviewed by two lectures as the experts coming from Curriculum and Technology of Education Program, Faculty of Education, State University of Surabaya, Indonesia. Criteria: $Y e s=1$, No $=0$

Table 3. Result of media experts review I and II

\begin{tabular}{|c|c|c|c|c|c|}
\hline \multirow{2}{*}{ Variable } & \multirow{2}{*}{ Sub Variable } & \multirow{2}{*}{ Indicator } & \multicolumn{2}{|c|}{ Score } & \multirow{2}{*}{ Percentage } \\
\hline & & & 1 & 0 & \\
\hline \multirow{8}{*}{ Media feasibility } & \multirow{8}{*}{ Web learning } & Goals accomplished & 2 & 0 & $100 \%$ \\
\hline & & Practical Instructions & 2 & 0 & $100 \%$ \\
\hline & & Updates & 2 & 0 & $100 \%$ \\
\hline & & Accuracy & 2 & 0 & $100 \%$ \\
\hline & & Language & 2 & 0 & $100 \%$ \\
\hline & & Participation rate & 2 & 0 & $100 \%$ \\
\hline & & Practical easiness & 2 & 0 & $100 \%$ \\
\hline & & visual/ layout design & 2 & 0 & $100 \%$ \\
\hline Average & & & & & $100 \%$ \\
\hline
\end{tabular}

Based on the table above, the data analyzed and has the $100 \%$ in average. The conclusion is that the web media used in the blended-learning model acknowledged as a good media. 


\subsection{Main Product Revision}

Instructional Design Experts' Revision, after getting the validation result coming from the expert, there was no suggestion to change the blended-learning media developed for audio/radio media development course. In short, there is no revision needed. Material Experts' Revision, after getting reviewed by the experts, there is no suggestion acquired related to the blended-learning model developed for audio/radio media development course. In conclusion, there is no revision needed. Media Experts' Revision, after getting the validation result coming from the expert, there was no suggestion to change the blended-learning media developed for audio/radio media development course. In short, there is no revision needed.

Started from the first stage up to the fifth stage stated above are the steps the researcher through in to develop the media. From the $6^{\text {th }}$ stage to the $10^{\text {th }}$ stage was not carried out by researcher because of limited funds and this research is aimed only to develop the blended-learning instructional materials for audio/radio development course for Curriculum and Technology of Education Program, Faculty of Education, State University of Surabaya, Indonesia.

Result of the research shows there is a positive impact on the advancement of blended learning syllabus in the learning process. Blended learning works as alternative solution from the deficiency of conventional method (lecturing). By implementing blended learning, the learning process gives out the interesting impression to the students, more engaging also motivating students more in learning and paying more attention to the materials delivered by their lecture. On the other hand, by its implementation, students can also learn by themselves outside the learning period, because it can be accessed by the students by online, complete with various quiz prepared by the lecture to deepen their understanding. Therefore, by using blended learning we can improve students' learning outcome. As the conclusion, the use of blended learning is effective on the audio/radio development course for Curriculum and Technology of Education Program, Faculty of Education, State University of Surabaya, Indonesia.

\section{Discussion}

This development was resulting in a kind of instructional media product that is the blended learning an instructional model that can be used in an instructional activity for audio/radio development course. After going through some stages and trials, the blended-learning model is finally acknowledged as a feasible media used on the course. Below is the discussion on the trials and revision acquired: Data is obtained from both instructional design experts, from all aspects reviewed by instructional design experts, it gets high-value percentage as much as $91.67 \%$. According to Arikunto (2015:31), the percentage is acknowledged as an excellent result, the learning model is feasible to be implemented for audio/radio media development course, Department of Curriculum and Technology of Education, Faculty of Education, State University of Surabaya, Indonesia; Data obtained from both materials experts, also all aspects reviewed by materials experts, it gets $100 \%$ perfect percentage. So that the learning model is sure applicable to be used in audio/radio media development class, Curriculum and Technology of Education, Faculty of Education, State University of Surabaya, Indonesia; Data obtained on both materials experts, from all aspects reviewed by media experts, it gets $100 \%$ perfect percentage. So that the learning model is sure applicable to be used in audio/radio media development class, Curriculum and Technology of Education, Faculty of Education, State University of Surabaya, Indonesia. Based on the data stated above, it could be referred that the instructional design of blended-learning models for the course development of audio media/radio that has been developed could answer the research question stated in the first chapter earlier, namely blended learning's instructional design which has been evolved to be applicable to the class.

Study on the development of blended learning syllabus for the course of advancement of audio/radio media is a new thing in Curriculum and Technology of Education Major in Faculty of Education, State University of Surabaya, Indonesia. In this context, blended learning is the act of combining both face-to-face learning activity and e-learning activity. Interesting thing in this study is: 1 . All learning activities, both face-to-cae and e-learning activity, arranged in the syllabus; 2 . There are new facilities in the e-learning named conference video so the lecture and the students can interact directly, beside using another common features on e-learning. State University of Surabaya is one of representative colleges in developing e-learning. If this program works, then it would be applied to all universities in Indonesia. Therefore, this study contributes to the advancement of education in Indonesia.

\section{Conclusion}

Based on the results of the development and the analysis of data, the conclusion is that the development of "blended learning's instructional design got audio/radio media development course" are applicable to be used for 
students majoring in Curriculum and Educational Technology Faculty of Education, State University of Surabaya, Indonesia. Based on the overall results of the research and discussion on this development, then given some suggestions are expected to increase the use of the results of this research development. The recommendation are stated as follows: Operating Suggestion, in the use of blended learning instructional design for the audio/radio media development course that has been developed, it expected that the lecturer would mark things as explained below; Teacher is not the only one as a learning sources, tutor's role is to be the facilitator that would affect the students to follow the learning activity that has been created, so that the course would be interesting and the students get higher motivation to be more active. The variation in learning activity created by using particular media and instructional design is considered as an effort to maximize the class sources to create an enjoyable learning environment; the use of blended learning model should come along with materials and lesson plan which were developed by the lecturer already. With those supporting sets, it would be easier for the tutor to deliver the course. Dissemination Suggestion, this development produced the instructional design of blended learning model for audio/radio media development course. If the media is used by any of educational institution, there should be re-identifying related on needs analysis, learning environment, students' characteristic, school's facilities, and etcetera. Every institution has its own peculiar and different matters. Development Suggestion, To the future researcher in the same focus, it suggested to create for another blended learning media with various materials, includes an interactive quiz, video conference and being more flexible, so that the learning activity implemented would be interesting.

\section{Acknowledgments}

Thanks to Prof. Dr. Mustaji, M.Pd who gave the first review for this paper, Prof. Dr. Ismet Basuki, M.Pd who gave the chance to participate in scientific writing training.

\section{References}

Arikunto, S. (2015). Proses Prosedur Penelitian: Suatu Pendekatan Praktik. Jakarta: Rineka Cipta.

Borg, W. R., \& Gall, M. D. (1989). Educational Research: An Introduction (5th ed.). New York: Longman.

Heinze, A., \& Procter, C. (2004). Reflections on the use of blended learning. In Education in a Changing Environment Conference Proceedings, University of Salford, Salford: Education Development Unit. Retrieved from http://www.ece.salford.ac.uk/proceedings/papers/ah_04.rtf

Joyce, B., \& Marsha, W. (2000). Models of Teaching. Amerika: A. Pearson Education Company.

Riyana, C. (2011). Teknologi Informasi dan Komunikasi dalam Pembelajaran: Blended Learning. Artikel TIK, 21-24.

Rovai, A. P., \& Jordan, H. M. (2004). Blended learning and sense of community: A comparative analysis with traditional and fully online graduate courses. The International Review of Research in Open and Distance Learning, 5(2). https://doi.org/10.19173/irrodl.v5i2.192

Rusman. (2015). Model-Model Pembelajaran: Mengembangkan Profesionalisme Guru. Jakarta: Raja Grafindo Persada.

Sadiman, A. (2016). Media Pendidikan. Jakarta: Raja Grafindo

Sagala, S. (2012). Konsep \& Makna Pembelajaran. Bandung: Alfabeta.

Semler, S. (2005). Use Blended Learning to Increase Learner Engagement and Reduce Training Cost. Retrieved from http://www.learningsim.com/content/lsnews/blended_learning1.html

Sharpe, R., Benfield, G., Roberts, G., \& Francis, R. (2006). The undergraduate experience of blended e-learning: $A$ review of $U K$ literature and practice. Retrieved from http://www.heacademy.ac.uk/assets/York/documents/ourwork/archive/blended_elearning_Full_review.pdf

Whitelock, D., \& Jelfs, A. (2003). Editorial: Journal of Educational Media Special Issue on Blended Learning. Journal of Educational Media, 28(2-3), 99-100. https://doi.org/10.1080/1358165032000177407

\section{Copyrights}

Copyright for this article is retained by the author(s), with first publication rights granted to the journal.

This is an open-access article distributed under the terms and conditions of the Creative Commons Attribution license (http://creativecommons.org/licenses/by/4.0/). 